
December 1938

\title{
CORRELATION OF AN ELECTROLYTIC CORROSION TEST WITH THE ACTUAL CORROSIVENESS OF SOILS
}

\author{
By Irving A. Denison and Robert B. Darnielle
}

\begin{abstract}
The corrosiveness of soils along a 128-mile section of a pipe-line system was estimated from data on the occurrence of leaks and length of line reconditioned and from the results of an electrolytic corrosion test. The development of leaks with time as influenced by reconditioning is illustrated for soils differing in corrosiveness. The corrosiveness of associated soils, as indicated by data on leaks and repairs and the results of the corrosion test, increases as the drainage becomes more deficient and as the soil becomes heavier in texture. The variation of corrosiveness with depth is illustrated for typical soil profiles. A rough linear correlation was observed between the actual corrosiveness of the soils and the results of the electrolytic test. The relative corrosiveness of the soils along approximately 80 percent of the total length of the pipe-line system was correctly indicated.
\end{abstract}

\section{CONTENTS}

1. Introduction

II. Description and classification of soils

III. Analysis of data on leaks and reconditioning

IV. Influence of soil properties on corrosiveness as indicated by leak frequency and percentage of line reconditioned

V. Corrosiveness of soils as measured by an electrolytic corrosion test.- 826

1. Description of test

2. Variation in corrosiveness with depth

3. Results of the corrosion test

VI. Comparison of actual corrosion on the pipe lines with corrosiveness

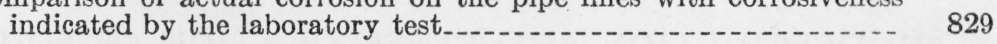

\section{INTRODUCTION}

An electrolytic test for measuring the corrosiveness of soils has been previously described. ${ }^{12}$ This test consists in the measurement of the polarization voltage at various current densities of a specially designed corrosion cell, in which the electrodes are steel and the electrolyte is the soil under test. The cell is constructed in such a way that the process of corrosion is similar to that in nature. The average current density corresponding to a definite range of potential is taken as the measure of the relative corrosiveness of the soil.

The results of the corrosion test have been shown to be closely associated with the loss in weight of the anode of the cell over a period

\footnotetext{
1 I. A. Denison, J. Research NBS 17, 363 (1936) RP918.

2 K. H. Logan, S. P. Ewing, and I. A. Denison. Symposium on Corrosion Testing Procedures, p. 95 (Am. Soc. Testing Materials, Philadelphis, Pa.; 1937).
} 
of 2 weeks and also with the results of the long-time field tests on the corrosion of metals in soils that are being conducted by the National Bureau of Standards. The data obtained from these field tests consist of accurate measurements of the loss of weight and depth of pits on 5 or 6 sets of 16 specimens each of wrought ferrous materials removed biennially from each of 47 carefully chosen test sites located in various parts of the United States. ${ }^{3}$

An accurate record of leaks and reconditioning on an extensive pipeline system, which was recently made available to the authors, provided a means of determining the true corrosiveness of the soil types which occur along the pipe lines. By comparing the relative corrosiveness of the soil types estimated by means of the electrolytic test with their actual corrosiveness on the pipe lines, the practical value of the test for locating corrosive soils may be judged by the extent of the correlation.

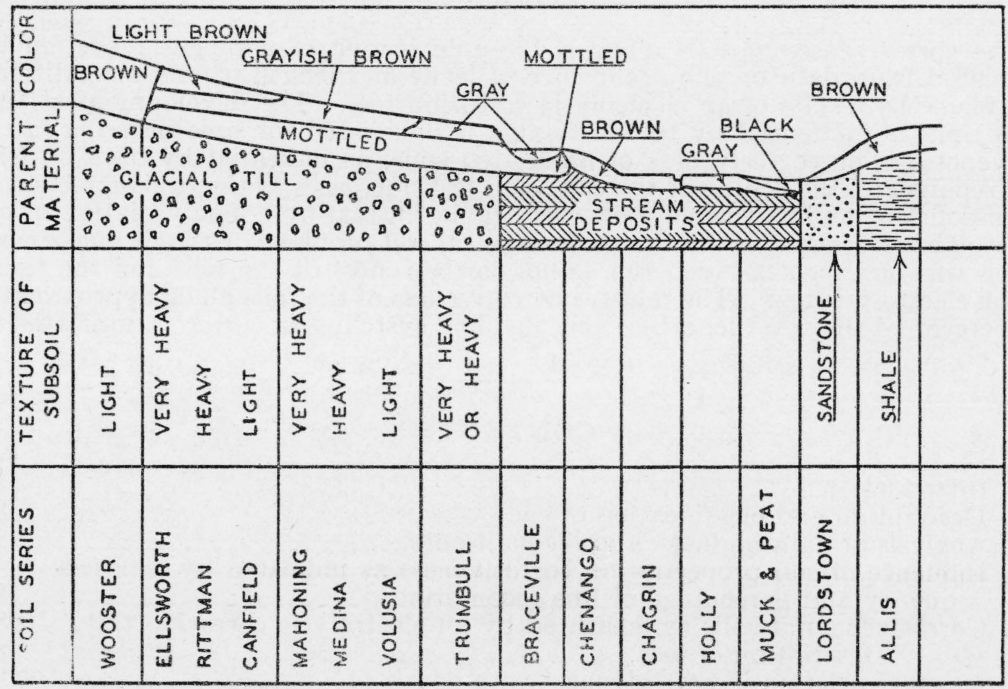

FIGURE 1.-Characteristics of soils in the region of glaciated sandstones and shales.

\section{DESCRIPTION AND CLASSIFICATION OF SOILS}

The pipe lines in the northwestern part of Ohio traverse what is known as the glacial lake region. The soils in this region have resulted chiefly from the weathering of glacial, or ice-laid, deposits and lacustrine, or lake-laid, deposits. Although the glacial drift is derived chiefly from limestone, there is a considerable admixture of shale, which accounts for the extremely heavy nature of the glacial deposits over this area. The very wet, poorly drained condition of much of this region has tended to retard the normal processes of weathering and soil development. The predominating glacial soils of this region belong to the Miami, Brookston, Nappanee, and Clyde series. The important lacustrine soils are those of the Plainfield, Fox, Newton, Toledo, and Wauseon series.

${ }^{3}$ K. H. Logan, J. Research NBS 16, 431 (1936) RP883. 
The pipe lines in northeastern Ohio lie wholly in the region of glacial soils derived from sandstone and shale. Where the parent rock is shale, the glacial material from which the soils were formed is a heavy clay. Soils developed from this material are heavy in texture, and consist of clays and clay loams. Where sandstone predominates, the soils are loams or silt loams, which are lighter in texture. As a result of different conditions of topography, drainage, and parent material, numerous soils which differ considerably in their characteristics have been developed. The predominant soils in this region, their distinguishing properties, and their physiographic relation to one another, are shown in figure 1. This figure in a slightly different form was prepared originally by Ewing. ${ }^{4}$ Detailed descriptions of these soils, as well as those of northwestern Ohio, have been given by Conrey. ${ }^{5}$

The field work, which was done in connection with previous studies, ${ }^{67}$ consisted in mapping the soil types occurring along these pipe lines and in the collection of samples for study in the laboratory. Borings were made at intervals of about $1 / 2$ mile and also wherever there was any question as to the type of soil. Where the soil profile appeared particularly well developed for the type, samples of soil were taken from each layer, or horizon, to a depth of about 36 inches. In general, however, at each location a single sample was taken from the horizon which appeared to be heaviest in texture.

\section{ANALYSIS OF DATA ON LEAKS AND RECONDITIONING}

The pipe-line system consists of five 8-inch parallel lines which were originally unprotected from corrosion. The pipe lines were laid at different times over a period of 18 years since 1889 , and their average age is 33 years. When a leak was reported, the line was uncovered at that point and a temporary repair was made by means of a leak clamp. The date and location of the leak were recorded.

Early in the life of these lines it was observed that, if several leaks occurred in short sections of the line, they were usually followed by other leaks with increasing frequency. Instead of repairing these leaks as they occurred, it was considered more economical to recondition the entire section in which the leak clamps became numerous. Accordingly, such sections were uncovered and the pipe replaced, or if its condition warranted, the pipe was repaired by welding the deeper pits and patching the larger corroded areas. In the severely corrosive locations the pipe was coated after the necessary repairs had been made. The date, location, and length of line reconditioned were recorded as a matter of routine. The fact that reconditioning was often done in sections of only 10 to 20 feet and seldom for more than a few thousand feet at one time, indicates that this work was done only when necessary.

S. P. Ewing, Soil Corrosion and Pipe-Line Protection (American Gas Association, New Y ork, N. Y.) 1938 .

5 G. W. Conrey. Bimonthly Bul. Ohio Agr. Expt. Sta. 11, 144 (1926), 11, 233 (1926).

$6 \mathrm{~S}$. P. Ewing, Distribution Committeo Report. American Gas Association (1934).

? I. A. Denison and S. P. Ewing, Soil Sei. 40, 287 (1935). 
The effect of reconditioning on the occurrence of leaks is illustrated in figures 2 and 3 , in which are shown the cumulative leaks per unit area and the cumulative percentage of line reconditioned, each plotted against time for the Mahoning silt loam, a corrosive soil, and for the Wooster loam, a mildly corrosive soil.

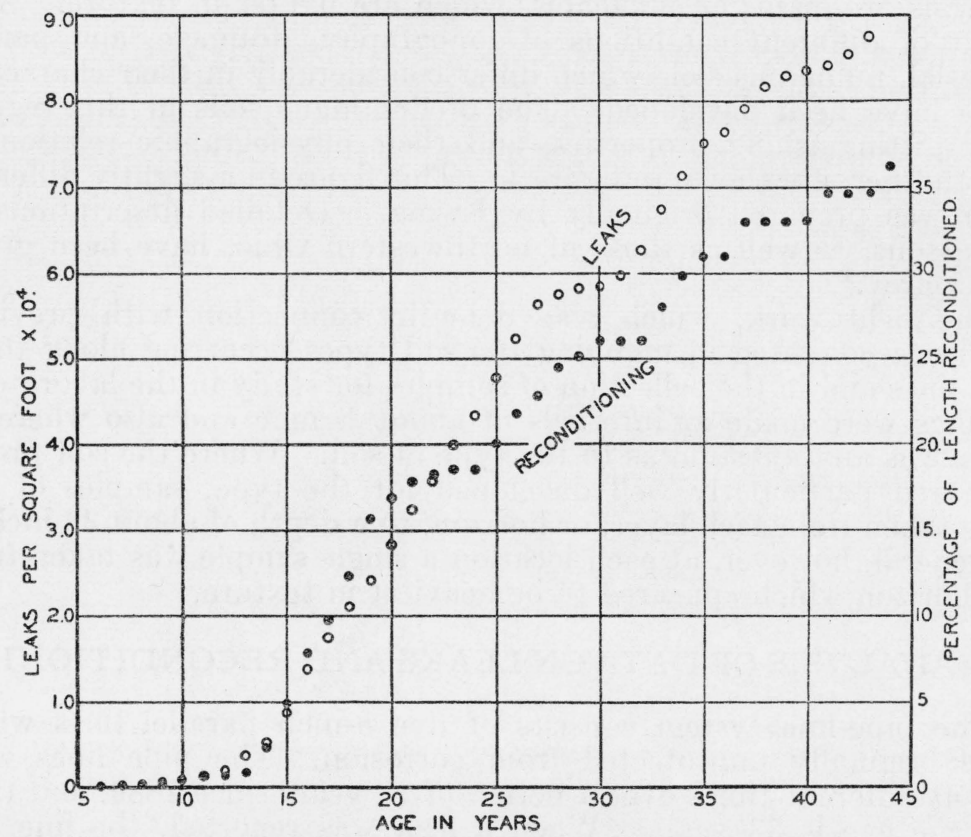

FIGURE 2.-Effect of time and reconditioning on the occurrence of leaks in the Mahoning silt loam.

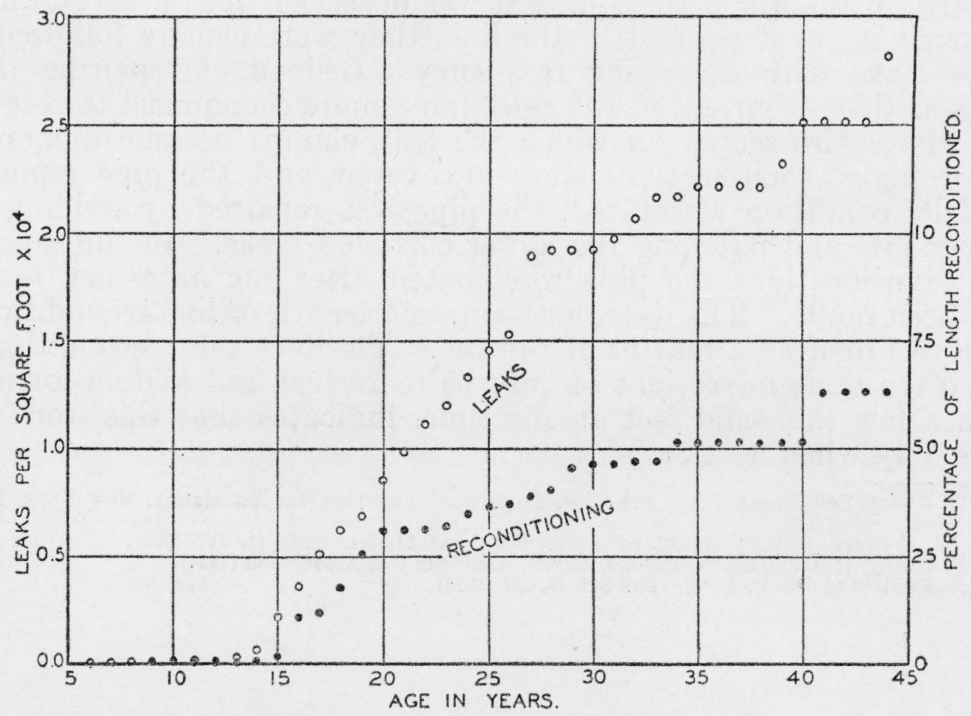

FIGURE 3.-Effect of time and reconditioning on the occurrence of leaks in the Wooster loam. 
It is seen from figures 2 and 3 that some sections of the lines were reconditioned soon after the first leaks appeared and that the effect of reconditioning on the occurrence of leaks has been very marked even from the beginning. If reconditioning had not been done, the leak curves would have curved upward after approximately 10 years and would have become steeper with time. It will be noted that, after the first 15 years, the curves for both leaks and reconditioning are approximately linear, that is, by doing a constant amount of reconditioning each year the development of leaks is held to a constant rate, which is probably the condition for most economical operation.

The number of leaks which occurred in each soil type and the proportion of the pipe reconditioned in the various soils during the 33-year average period are summarized in table 1. Leaks and repairs within 250 feet of an intersection with a stream, road, or railroad crossing are not included. As the data apply to five parallel pipe lines, the recorded length of pipe is about five times that of the corresponding soil type.

TABLE 1.-Number of leaks and reconditioned length of pipe lines in the soil type

\begin{tabular}{|c|c|c|c|c|c|}
\hline \multicolumn{2}{|l|}{ Soil } & \multirow{2}{*}{$\begin{array}{l}\text { Length } \\
\text { of pipe } \\
\text { lines in } \\
\text { thou- } \\
\text { sands } \\
\text { of feet }\end{array}$} & \multirow{2}{*}{$\begin{array}{c}\text { Num- } \\
\text { ber of } \\
\text { leaks } \\
\text { per } \\
10,000 \\
\text { feet } \\
\text { A }\end{array}$} & \multirow{2}{*}{$\begin{array}{c}\begin{array}{c}\text { Recon- } \\
\text { di- } \\
\text { tioned } \\
\text { length }\end{array} \\
\text { B }\end{array}$} & \multirow{2}{*}{ Ratio } \\
\hline Type & $\begin{array}{c}\text { Sym- } \\
\text { bol }\end{array}$ & & & & \\
\hline $\begin{array}{l}\text { Wooster fine sandy loam } \\
\text { Trumbull clay loam } \\
\text { Muck } \\
\text { Genesee silt loam } \\
\text { Nappanee clay loam }\end{array}$ & $\begin{array}{l}W f \\
T \\
M u \\
G \\
N\end{array}$ & $\begin{array}{r}2.5 \\
28.6 \\
8.0 \\
6.5 \\
47.3\end{array}$ & $\begin{array}{l}28.0 \\
20.2 \\
18.8 \\
18.5 \\
15.9\end{array}$ & $\begin{array}{l}\% \\
34.5 \\
44.1 \\
32.4 \\
26.1 \\
54.8\end{array}$ & $\begin{array}{l}1.2 \\
2.2 \\
1.7 \\
\text { 1. } 4 \\
\text { 3. } 4\end{array}$ \\
\hline $\begin{array}{l}\text { Chagrin silt loam and fine sandy loam } \\
\text { Mahoning silt loam } \\
\text { Wauseon-like soils. } \\
\text { Holly clay loam } \\
\text { Lorain clay loam }\end{array}$ & $\begin{array}{l}C h \\
M \\
W a \\
H \\
K c\end{array}$ & $\begin{array}{r}43.3 \\
475.7 \\
46.5 \\
37.4 \\
14.0\end{array}$ & $\begin{array}{l}13.6 \\
12.8 \\
11.8 \\
11.7 \\
10.0\end{array}$ & $\begin{array}{l}21.6 \\
19.8 \\
66.2 \\
22.6 \\
29.2\end{array}$ & $\begin{array}{l}1.6 \\
1.5 \\
5.6 \\
1.9 \\
2.9\end{array}$ \\
\hline $\begin{array}{l}\text { Ellsworth silt loam } \\
\text { Volusia silt loam } \\
\text { Canfield silt loam } \\
\text { Volusia loam } \\
\text { Wauseon fine sandy loam }\end{array}$ & $\begin{array}{l}E \\
V \\
C a \\
V l \\
W\end{array}$ & $\begin{array}{r}49.3 \\
294.1 \\
132.4 \\
35.5 \\
19.0\end{array}$ & $\begin{array}{l}9.6 \\
8.1 \\
8.1 \\
7.9 \\
6.9\end{array}$ & $\begin{array}{r}14.8 \\
19.0 \\
6.5 \\
6.0 \\
7.6\end{array}$ & $\begin{array}{r}1.5 \\
2.3 \\
.8 \\
.8 \\
1.1\end{array}$ \\
\hline $\begin{array}{l}\text { Till. } \\
\text { Newton fine sandy loam } \\
\text { Lordstown fine sandy loam } \\
\text { Crosby silt loam }\end{array}$ & $\begin{array}{l}T i \\
C \\
N f \\
L \\
C s\end{array}$ & $\begin{array}{r}46.6 \\
104.0 \\
18.3 \\
25.5 \\
35.0\end{array}$ & $\begin{array}{l}6.5 \\
6.0 \\
6.0 \\
5.5 \\
4.9\end{array}$ & $\begin{array}{r}12.2 \\
11.0 \\
6.5 \\
4.5 \\
3.4\end{array}$ & $\begin{array}{r}1.9 \\
1.9 \\
1.1 \\
.8 \\
.7\end{array}$ \\
\hline $\begin{array}{l}\text { Sands and sandy loams undifferentiated. } \\
\text { Wooster loam } \\
\text { Brookston clay loam } \\
\text { Lorain fine sandy loam. } \\
\text { Miami silt loam and fine sandy loam }\end{array}$ & $\begin{array}{l}S \\
W l \\
B c \\
K \\
M l\end{array}$ & $\begin{array}{r}363.0 \\
269.1 \\
245.8 \\
61.5 \\
68.5\end{array}$ & $\begin{array}{l}4.9 \\
4.2 \\
4.0 \\
3.9 \\
2.6\end{array}$ & $\begin{array}{r}3.9 \\
4.6 \\
20.4 \\
6.9 \\
2.1\end{array}$ & $\begin{array}{r}.8 \\
1.1 \\
5.0 \\
1.8 \\
.8\end{array}$ \\
\hline $\begin{array}{l}\text { Clyde clay loam } \\
\text { Lucas fine sandy loam }\end{array}$ & $\begin{array}{l}A \\
L f\end{array}$ & $\begin{array}{l}40.3 \\
14.5\end{array}$ & $\begin{array}{l}2.5 \\
0\end{array}$ & $\begin{array}{l}5.3 \\
0\end{array}$ & $\begin{array}{r}2.1 \\
-----\end{array}$ \\
\hline Average. & & & & & 1.8 \\
\hline
\end{tabular}

The length of pipe in each type of soil is a rough criterion of the reliability of the data for that soil. Obviously, more weight should be attached to the data for those soils, such as the Mahoning silt loam, Volusia silt loam and the undifferentiated sands, which contain large footages of pipe, than to those soils of slight extent, such as the Wooster 
fine sandy loam, muck, and the Genesee silt loam, in which the footage of pipe is relatively small. 'The soil which was designated as Lorain clay loam in previous papers is designated in this paper as Lorain fine sandy loam and vice versa. Later examination of the field notes and the soil samples, as well as data from other sources, indicated that these soils were originally incorrectly mapped.

Before any comparison can be made between the actual corrosiveness of the soils and the corrosiveness predicted from laboratory tests, it is obviously necessary to decide whether (a) the number of leaks, or (b) the reconditioned length, or (c) some combination of the two, should be taken as the measure of the corrosion that has actually occurred. As both the number of leaks and the proportion of the line reconditioned are dependent upon the corrosiveness of the soils, either one of these factors might be used as the criterion of corrosiveness. In fact, if they are found to be proportional to each other, that is, if they put the soils in the same order, it is immaterial which one is used.

The ratios in the last column of table 1 show that there is a rough proportionality between these two quantities for all but three of the soils, namely, Nappanee clay loam, "Wauseon-like" soils, and the Brookston clay loam, for which the proportionality factor differs from the average by considerably more than 50 percent of the average factor. As the pipe lines in the three soil types mentioned were generally close to roads, reconditioning could be done more cheaply than in less accessible locations. In such soils, the number of leaks is probably a more reliable criterion of relative corrosiveness than is the extent of reconditioning.

Although the ratios in table 1 are only roughly constant, the deviations from constancy are relatively small in comparison with the large differences in the corrosiveness of the soils indicated by the leak frequencies. Hence, it is doubtful whether the greater or less extent of reconditioning done in proportion to the leak frequencies in individual soils would appreciably affect the order of corrosiveness shown by leak frequency alone. For purposes of correlation, the number of leaks per unit length may therefore be taken as a simple, approximate measure of the actual corrosiveness of the soils.

\section{INFLUENCE OF SOIL PROPERTIES ON CORROSIVENESS}

\section{AS INDICATED BY LEAK FREQUENCY AND PERCENT- AGE OF LINE RECONDITIONED}

In order to show the effect of soil properties on corrosion, table 2 has been prepared for a group of associated soil types which occur along the eastern part of the lines. The soils are arranged according to the degree of development of the soil profile, which is determined by texture, drainage, and the nature of the material from which the soil is derived. Corrosiveness is indicated by the number of leaks per 10,000 feet which have occurred during the average period of 33 years and by the percentage of the line reconditioned over the same period. If the corrosion data are compared from left to right, it is seen that the corrosiveness of the soils decreases as the drainage improves, as indicated by the color of the surface soil and the depth at which mottling appears. If the values are compared vertically, it is seen that corrosiveness increases as the soils become heavier in texture. 
TABLE 2.-Degree of development of associated soil series and corrosiveness, as indicated by leak density and percentage of line reconditioned in 33 years

\begin{tabular}{|c|c|c|c|c|c|c|c|c|c|c|}
\hline \multirow[b]{3}{*}{$\begin{array}{l}\text { Color of surface soil- } \\
\text { Mottling of } A_{2} \text { hori- } \\
\text { zon. } \\
\text { Mottling of } B \text { hori- } \\
\text { zon. } \\
\text { Mottling of } C \text { hori- } \\
\text { zon. }\end{array}$} & \multicolumn{10}{|c|}{ Degree of development } \\
\hline & \multicolumn{3}{|c|}{1} & \multicolumn{2}{|l|}{2} & \multicolumn{2}{|l|}{3} & \multicolumn{3}{|c|}{4} \\
\hline & \multicolumn{3}{|c|}{ 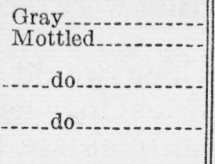 } & \multicolumn{2}{|c|}{$\begin{array}{l}\text { Gray brown } \\
\text { Mottled........... }\end{array}$} & \multicolumn{2}{|c|}{$\begin{array}{l}\text { Light brown } \\
\text { Mottled. } \\
\text { do }\end{array}$} & \multicolumn{3}{|c|}{$\begin{array}{l}\text { Brown. } \\
\text { No mottling. } \\
\text { Do. } \\
\text { Do. }\end{array}$} \\
\hline $\begin{array}{l}\text { Distinguishing } \\
\text { characteristics of } B \\
\text { horizon }\end{array}$ & Series & 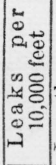 & 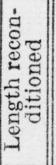 & Series & 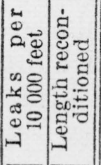 & Series & 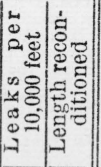 & Series & 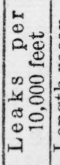 & 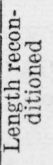 \\
\hline $\begin{array}{l}\text { Light............. } \\
\text { Heavy......... } \\
\text { Very heavy.... }\end{array}$ & Trumbull & $\begin{array}{c}-\cdots \\
20.2\end{array}$ & \begin{tabular}{|c||}
$\%$ \\
44.1 \\
\end{tabular} & $\begin{array}{l}\text { Volusia ... } \\
\text { Medina _.. } \\
\text { Mahoning }\end{array}$ & \begin{tabular}{|c|c|} 
& $\%$ \\
8.1 & 19.0 \\
$(\mathrm{a})$ & $(\mathrm{a})$ \\
12.8 & 19.8 \\
\end{tabular} & $\begin{array}{l}\text { Canfield. - } \\
\text { Rittman - } \\
\text { Ellsworth- }\end{array}$ & \begin{tabular}{|c|c||} 
& $\%$ \\
8.1 & 6.5 \\
$(\mathrm{a})$ & $(\mathrm{a})$ \\
9.6 & 14.8
\end{tabular} & \begin{tabular}{|c} 
Wooster.- \\
\end{tabular} & \begin{tabular}{|c|}
4.2 \\
\hdashline .2 \\
\hdashline
\end{tabular} & \begin{tabular}{l}
$\%$ \\
4.6 \\
\hdashline.. \\
\hdashline
\end{tabular} \\
\hline
\end{tabular}

a Series not identified along pipe line.

The relation shown in table 2 between soil conditions and corrosion can be explained on the basis of our present knowledge of corrosion processes in soils. In addition to the corrosive effect of the greater acidity and conductivity of the heavy and imperfectly drained soils, the relatively large leak frequencies and amounts of pipe repaired in such soils are to be ascribed largely to the fact that under conditions of poor aeration the rate of pitting changes relatively little with time. On the other hand, under conditions of good aeration, there is usually a marked tendency for the rate of pitting to decrease with time.

The relation between the aeration of the soil and depth of pitting is attributed to the inhibiting action of the corrosion products that are precipitated in contact with the corroding areas under conditions of good aeration. The failure of corrosion products to protect under conditions of poor drainage evidently overbalances the opposing effect of the relatively great cathodic polarization that would be expected in poorly drained soils because of the deficiency of oxygen. It should be noted, however, that good aeration is not in itself a sufficient condition for the precipitation of corrosion products. In the presence of a high concentration of salts in many soils, or of extreme acidity, the products of corrosion may remain soluble even when completely oxidized.

The number of leaks, averaging four per 10,000 feet, shown in table 2 to have occurred in the Wooster loam, which is one of the least corrosive soils along the pipe lines, indicates that some leaks may occur even in soils which have properties not ordinarily associated with corrosion. This soil occupies rolling uplands where surface drainage is good. It is coarse in texture, has an open, porous structure, contains very little soluble material (average resistivity $-8,000 \mathrm{ohm}-\mathrm{cm}$ ), and its acidity is normal for the well-weathered soils of the humid regions. Yet a fairly large number of leaks developed in this soil before the line was 15 years old. This same general condition applies likewise to a 
large body of coarse, well-drained soils of high resistivity, which are classified as sands. In these soils an average of five leaks per 10,000 feet developed.

A probable explanation for the occurrence of even a small number of leaks in soils in which leaks would not be predicted, is that corrosion did not occur generally throughout that soil type, but was confined to restricted areas of more corrosive soil types, that were too small in their extents to be properly classified.

The occurrence of some leaks in soils which would ordinarily be considered noncorrosive raises the question as to whether any soil types occurring under similar climatic conditions are actually noncorrosive. Since some degree of variability is characteristic of soil types in general, it is difficult to escape the conclusion that in the usual acid soils of the eastern United States, exclusive of certain very well drained or mountainous areas, there are very few soils in which some leaks in a pipe line of average diameter and wall thickness will not develop within 30 years.

\section{CORROSIVENESS OF SOILS AS MEASURED BY AN ELECTROLYTIC CORROSION TEST}

\section{DESCRIPTION OF TEST}

The corrosiveness of the soil samples collected along the pipe lines was determined in the laboratory from the relation between current density and potential in a corrosion cell in which the anode and cathode are steel and the electrolyte is the soil under test. By using as the cathode a steel screen which is more readily accessible to air than the anode, the electrodes are aerated differentially and the cell develops its own electromotive force. However, an externally applied electromotive force was used in the tests here described. Current densitypotential curves were obtained by plotting the potentials existing in such cells at different current densities. The average current density over the range of voltage between 0 and 0.3 volt was tentatively selected as the criterion of the relative corrosiveness of the soils. The construction of the test cells, preparation of the cells for test, and the method of making the electrical measurements were described in a previous publication. ${ }^{8}$

\section{VARIATION IN CORROSIVENESS WITH DEPTH}

It is generally recognized that the properties of soils may vary greatly with depth. A familiar example of this variation is the frequent occurrence of a layer of heavy clay below the surface soil. An abrupt change in reaction from high acidity to alkalinity within a few inches is another illustration of the variation which may be encountered between adjacent soil horizons. It was therefore necessary to study the manner in which corrosiveness varied throughout the profiles of the important soil types present.

In table 3 the characteristies of the horizons of 8 soil types are shown, together with the corrosiveness of the various horizons, as indicated by the laboratory test. The profile shown for the "Wauseon-like" soils is typical of rather extensive bodies of soil observed in the glacial

${ }^{8}$ K. H. Logan, S. P. Ewing, and I. A. Denison, Symposium on Corrosion Testing Procedures, p. 95 (Am. Soc. Testing Materials, Philadelphia, Pa.; 1937). 
lake region which have not been exactly classified. This profile resembles that of the Wauseon fine sandy loam, but it does not have the dark sandy subsoil extending to about 36 inches, which is typical of the true Wauseon soils.

TABLE 3.--Relative corrosiveness of horizons of typical soil profiles, as indicated by the electrolytic corrosion test

\begin{tabular}{|c|c|c|c|c|c|}
\hline \multicolumn{3}{|c|}{ SOILS OF NORTHEASTERN OHIO } & \multicolumn{3}{|c|}{ SOILS OF NORTHWESTERN OHIO } \\
\hline Depth & $\begin{array}{l}\text { Current } \\
\text { density }\end{array}$ & Description & Depth & $\begin{array}{l}\text { Current } \\
\text { density }\end{array}$ & Description \\
\hline \multicolumn{3}{|c|}{ WOOSTER SILT LOAM } & \multicolumn{3}{|c|}{ MIAMI SILT LOAM } \\
\hline $\begin{array}{l}\quad i n . \\
0 \text { to } 9 \\
9 \text { to } 15 \\
15 \text { to } 27 \\
\text { Below } 27\end{array}$ & $\begin{array}{r}m a / d m^{2} \\
1.0 \\
2.1 \\
3.5 \\
2.4\end{array}$ & $\begin{array}{l}\text { Brown silt loam. } \\
\text { Yellowish-brown silt loam. } \\
\text { Yellowish - brown compact } \\
\text { silt loam. } \\
\text { Yellowish-brown loam to silt } \\
\text { loam. }\end{array}$ & $\begin{array}{l}\quad i n \\
0 \text { to } 9 \\
9 \text { to } 17- \\
17 \text { to } 27 \\
\text { Below } 27\end{array}$ & $\begin{array}{r}m a / d m^{2} \\
2.0 \\
6.1 \\
6.8 \\
\end{array}$ & $\begin{array}{l}\text { Brownish-gray silt loam. } \\
\text { Pale yellowish - brown silt } \\
\text { loam. } \\
\text { Dull yellowish-brown silty } \\
\text { clay. } \\
\text { Calcareous clay. }\end{array}$ \\
\hline \multicolumn{3}{|c|}{ VOLUSIA SILT LOAM } & \multicolumn{3}{|c|}{ BROOKSTON CLAY LOAM } \\
\hline $\begin{array}{l}0 \text { to } 7 \\
7 \text { to } 18 \\
18 \text { to } 29\end{array}$ & $\begin{array}{r}2.2 \\
5.7 \\
10.8 \\
3.3\end{array}$ & $\begin{array}{l}\text { Brownish-gray silt loam. } \\
\text { Mottled-gray and yellowish- } \\
\text { brown silt loam. } \\
\text { Mottled-gray and yellowish- } \\
\text { brown heavy silt loam. } \\
\text { Mottled loam to silt loam }\end{array}$ & $\begin{array}{l}0 \text { to } 7 \\
7 \text { to } 22 \\
22 \text { to } 38 \\
\text { Below } 38\end{array}$ & $\begin{array}{l}4.1 \\
9.2 \\
8.1 \\
7.2\end{array}$ & $\begin{array}{l}\text { Gray-black clay loam. } \\
\text { Mottled-gray and yellowish- } \\
\text { brown clay loam. } \\
\text { Mottled yellowish-brown and } \\
\text { yellowish gray clay. } \\
\text { Calcareous clay. }\end{array}$ \\
\hline \multicolumn{3}{|c|}{ MAHONING SILT LOAM } & \multicolumn{3}{|c|}{ NAPPANEE CLAY LOAM } \\
\hline $\begin{array}{l}0 \text { to } 7 \\
7 \text { to } 13 \ldots \\
13 \text { to } 23 \ldots \\
\text { Below } 23 \ldots\end{array}$ & $\begin{array}{r}2.8 \\
6.1 \\
11.1 \\
11.1\end{array}$ & $\begin{array}{l}\text { Brownish-gray silt loam. } \\
\text { Mottled-gray and yellowish- } \\
\text { brown silty clay loam. } \\
\text { Mottled-gray and yellowish- } \\
\text { brown silty clay. } \\
\text { Brownish-drab heavy silty } \\
\text { clay. }\end{array}$ & $\begin{array}{l}0 \text { to } 8 \\
8 \text { to } 25 \\
\text { Below } 25\end{array}$ & $\begin{array}{l}2.7 \\
8.8 \\
7.9\end{array}$ & $\begin{array}{l}\text { Grayish-yellow heavy clay } \\
\text { loam. } \\
\text { Mottled yellowish-brown and } \\
\text { gray heavy clay. } \\
\text { Dull yellowish-brown cal- } \\
\text { careous clay. }\end{array}$ \\
\hline \multicolumn{3}{|c|}{ TRUMBULL CLAY LOAM } & \multicolumn{3}{|c|}{ WAUSEON-LIKE SOILS } \\
\hline $\begin{array}{l}0 \text { to } 9 \\
9 \text { to } 26 \\
26 \text { to } 38\end{array}$ & $\begin{array}{r}3.6 \\
4.7 \\
11.2\end{array}$ & $\begin{array}{l}\text { Dark-gray clay loam. } \\
\text { Drab-gray silty clay, mottled } \\
\text { with rusty brown. } \\
\text { Drab-gray clay, mottled with } \\
\text { rusty brown. }\end{array}$ & $\begin{array}{l}0 \text { to } 9 \\
9 \text { to } 28 \ldots \\
\text { Below } 28\end{array}$ & $\begin{array}{r}2.5 \\
12.7 \\
5.8\end{array}$ & $\begin{array}{l}\text { Gray-black finesandy loam. } \\
\text { Yellowish-brown silty clay } \\
\text { loam. } \\
\text { Calcareous clay with decom- } \\
\text { posed shale. }\end{array}$ \\
\hline
\end{tabular}

It will be observed in table 3 that as the soil becomes heavier in texture from the surface downward, the corrosiveness of the soil likewise increases. The upper subsoil is invariably heavier and more corrosive than the surface soil. In several profiles the maximum corrosiveness and heaviest texture occur in the lower subsoil at depths greater than 1 to 2 feet. Increase in corrosiveness with depth throughout the profile is characteristic of those soils which have developed from heavy-textured parent material that is normally acid in reaction, for example, the Mahoning silt loam and the Trumbull clay loam. Soils which have developed from coarse parent material, for example, the Wooster and Volusia silt loams, become less corrosive in the lower part of the profile. 
The general tendency, observed in table 3 , for corrosiveness to increase as the soil becomes heavier in texture and as the drainage becomes less perfect is in agreement with the conclusions reached after comparing the properties of various soil types with the leak frequency and reconditioned length in these types (table 2). It would seem that in the corrosion cell, as in nature, maintenance of the products of corrosion in the deoxidized, and hence more soluble, condition has a greater effect on the rate of corrosion in the soils studied than has the high cathodic polarization, which is characteristic of heavy, poorly drained soils.

In view of the marked differences in the corrosiveness of certain soils at different depths, it is evident that in sampling soils for corrosion tests, the depth at which the sample is taken must be carefully considered. It is probable that the pipe line will be in contact at some points with soil from the most corrosive horizon of the soil profile, which might therefore logically be selected for the test. The procedure adopted in the present study was to take samples from that horizon which is heaviest in texture, a practice which was supported by the results of the corrosion tests. In general, however, it would be preferable to study in advance of the actual survey the variation with depth in the corrosiveness of each important soil type, using the cell test as a measure of corrosion. From the results of this preliminary study, the depth at which soil samples should be taken could be determined for each soil type.

\section{RESULTS OF THE CORROSION TEST}

The mean values of the average current density in the potential range from 0 to 0.3 volt are shown in table 4 . In general, the number of samples tested in each soil type was about in proportion to the length of pipe contained in that soil. The reliability of the data for a particular soil type depends, therefore, on the length of pipe exposed to that type. Computation of the standard errors of the mean current densities showed that these errors were practically all less than 25 percent of the mean. The latter may therefore be used directly as the measure of corrosiveness determined by the electrolytic test.

TABLE 4.-Corrosiveness of soils, as indicated by the electrolytic test

\begin{tabular}{|c|c|c|c|c|c|}
\hline Soll symbol 1 & $\begin{array}{c}\text { Number } \\
\text { of samples } \\
\text { tested }\end{array}$ & $\begin{array}{l}\text { A verage } \\
\text { current } \\
\text { density } \\
\text { frcm } 0 \text { to } \\
0.3 \mathbf{v}\end{array}$ & Soil symbol 1 & $\begin{array}{c}\text { Number } \\
\text { of samples } \\
\text { tested }\end{array}$ & $\begin{array}{l}\text { Average } \\
\text { current } \\
\text { density } \\
\text { from } 0 \text { to } \\
0.3 \mathrm{v}\end{array}$ \\
\hline $\begin{array}{l}M u \\
W a \\
A \\
N \\
B c\end{array}$ & $\begin{array}{l}2 \\
1 \\
3 \\
3 \\
6\end{array}$ & $\begin{array}{r}m a / d m^{2} \\
15.8 \\
12.7 \\
9.1 \\
8.1 \\
8.0\end{array}$ & $\begin{array}{l}K c \\
C a \\
C \\
C s\end{array}$ & $\begin{array}{r}2 \\
7 \\
8 \\
2 \\
15\end{array}$ & $\begin{array}{r}m a / d m \\
7.8 \\
4.6 \\
4.3 \\
4.1 \\
3.3\end{array}$ \\
\hline $\begin{array}{l}M \\
M \\
M f\end{array}$ & $\begin{array}{r}38 \\
8 \\
4 \\
4 \\
2\end{array}$ & $\begin{array}{l}7.8 \\
7.2 \\
7.1 \\
6.4 \\
6.3\end{array}$ & $\begin{array}{l}W \\
K \\
T i \\
Q \\
W f\end{array}$ & $\begin{array}{r}12 \\
3 \\
6 \\
3 \\
2\end{array}$ & $\begin{array}{l}2.7 \\
2.5 \\
2.4 \\
2.3 \\
2.2\end{array}$ \\
\hline $\begin{array}{l}V W \\
W \\
T \\
V \\
V\end{array}$ & $\begin{array}{r}5 \\
2 \\
8 \\
29\end{array}$ & $\begin{array}{l}6.1 \\
5.9 \\
5.8 \\
5.7\end{array}$ & 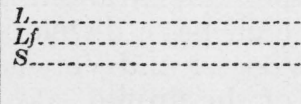 & $\begin{array}{l}2 \\
2 \\
2\end{array}$ & $\begin{array}{l}1.3 \\
1.2 \\
0.6\end{array}$ \\
\hline
\end{tabular}

1 For identiflation of symbols, see table 1 , page 823 . 
In general, the soil types which show the highest values of current density are heavy in texture or poorly drained, or both. Conversely, low values of current density are usually associated with well-drained soils of coarse texture.

\section{COMPARISON OF ACTUAL CORROSION ON THE PIPE LINES WITH CORROSIVENESS INDICATED BY THE LABORATORY TEST}

The relation between the corrosiveness of the soil types, as indicated by the laboratory test, and their actual corrosiveness was studied by plotting the mean current densities of the soil types against the corresponding number of leaks per 10,000 feet. It was observed that the points representing extensive soils, for which the laboratory and field data were most reliable, conformed well to a straight line.

In order to decide whether the correlation for the data as a whole was sufficient for the test to be of practical value, the soils were divided into five groups according to successive ranges of leak frequency. The current densities corresponding to these ranges of leak frequency were then calculated from the slope of the line which showed the average relation between the field and laboratory data. The soils were then placed in five groups according to current density, and the agreement between the classifications on the bases, respectively, of leak frequency and of current density was noted. For example, a difference of 0 indicates complete agreement, a difference of +1 means that the electrolytic test places the soil in one group higher (that is, more corrosive) than the group in which it properly belongs, and vice versa. Since the limits of the groups are necessarily arbitrary, an agreement of plus or minus one group is evidence of fair correlation.

TABLE 5.-Classification of soils according to the electrolytic test

\begin{tabular}{|c|c|c|c|c|c|}
\hline Group.............. & $\mathrm{I}$ & II & III & IV & V \\
\hline Leaks per 10,000 feet...... & 0 to 4 & 4.1 to 8 & 8.1 to 12 & 12.1 to 16 & $>16$ \\
\hline \multirow[t]{2}{*}{ Current density (ma/dm²) } & 0 to 2.3 & 2.4 to 4.6 & 4.7 to 6.9 & 7.0 to 9.2 & $>9.3$ \\
\hline & $\begin{array}{lr}B c & +3 \\
K & +1 \\
M l & +2 \\
A & +3 \\
L f & 0\end{array}$ & $\begin{array}{lr}V l & +1 \\
W & +1 \\
T i & 0 \\
C & 0 \\
N f & +1 \\
L & -1 \\
C s & 0 \\
S & -1 \\
W l & 0\end{array}$ & $\begin{array}{lr}K c & +1 \\
E & +1 \\
V & 0 \\
C a & -1 \\
W a & +2\end{array}$ & $\begin{array}{lr}N & 0 \\
C h & -2 \\
M & 0 \\
H & 0\end{array}$ & $\begin{array}{lr}W f & -4 \\
T & -2 \\
M u & 0 \\
G & -4\end{array}$ \\
\hline
\end{tabular}

\begin{tabular}{|c|c|}
\hline \multicolumn{2}{|c|}{ Summary } \\
\hline Difference & $\begin{array}{c}\text { Number of } \\
\text { soils }\end{array}$ \\
\cline { 2 - 2 } & \\
\hline 0 & 10 \\
1 & 9 \\
2 & 4 \\
3 & 2 \\
4 & 2 \\
\hline
\end{tabular}


It is seen in table 5 that 19 of the 27 soils, that is, 70 percent, showed at least fair correlation between the electrolytic test and the reported leaks. Consideration of the length of pipe (or soil) involved, as listed in table 1, shows that on over 80 percent of the actual length of the pipe lines, the electrolytic test would have correctly predicted (that is, \pm 1 group) the rela tive corrosiveness of the soil.

The fact that of the four soils $(A, B c, G$, and $W f)$ that showed poor correlation, a total of only 14 samples was tested, as compared with a general average of about 7 samples per soil, at least indicates that the samples of these soils may not have been representative. These results indicate that any improvement in the ability to predict soil behavior from the electrolytic test is more likely to result from an improvement in sampling than in the electrolytic test itself.

The authors express their appreciation to S. P. Ewing for the use of certain figures and for many helpful suggestions. They also acknowledge the assistance of I. C. Frost, by whom most of the corrosion tests were made.

Washington, April 12, 1938. 